\title{
Penerapan Prinsip Pembangunan Berkelanjutan dan Ekonomi Berwawasan dalam Peraturan Perundang- Undangan Penggunaan Kawasan Hutan dalam Rangka PSN Pasca Pengesahan Perpres 66/2020
}

\author{
Dalila Doman ${ }^{1}$ dan Nadia Doman ${ }^{2}$
}

\begin{abstract}
Abstrak
Prinsip pembangunan berkelanjutan dan ekonomi berwawasan lingkungan merupakan amanat Pasal 33 ayat (4) UUD NRI 1945. Oleh karena itu, kedua amanat ini harus diterapkan dalam peraturan perundang-undangan di bawahnya termasuk di sektor kehutanan dan perekonomian nasional. Pemerintah menilai percepatan pelaksanaan Proyek Strategis Nasional (PSN) tidak hanya menumbuhkan perekonomian nasional, tetapi juga dapat menjaga kondisi ekonomi nasional selama pandemi COVID-19. Penilaian tersebut membuat pemerintah mengesahkan Perpres 66/2020 yang mengatur pendanaan pengadaan tanah dalam rangka pelaksanaan PSN, salah satunya di kawasan hutan. Peraturan pendanaan pengadaan tanah di kawasan hutan ini dikhawatirkan memberikan ancaman bagi penerapan pembangunan berkelanjutan dan ekonomi berwawasan lingkungan di sektor kehutanan. Oleh karena itu, artikel ini akan menganalisis apakah pembangunan berkelanjutan dan ekonomi berwawasan lingkungan di sektor kehutanan terancam dengan adanya peraturan ini.
\end{abstract}

Kata kunci: Pembangunan berkelanjutan, ekonomi berwawasan lingkungan, Proyek Strategis Nasional, kawasan hutan.

\section{Abstract}

Sustainable development and environmental perspective in economics are the mandates of The Constitution of the Republic of Indonesia of 1945. Therefore, these two principles shall be implemented in the regulations beneath, including the forestry sector and national development. The government assumes that acceleration of the National Strategic Project (PSN) could not only increase the national economy growth, but also preserve it during the COVID-19 pandemic. That assumption made the government enact the Presidential Regulation No. 66 of 2020, which regulates land acquisition financing in PSN implementation, including in the forest areas. This land acquisition financing in the forest area regulation is expected to possess $a$ threat to sustainable development and environmental perspective in economics implementation

\footnotetext{
${ }^{1}$ Penulis adalah peneliti di Indonesian Center for Environmental Law.

${ }^{2}$ Penulis memiliki pengalaman kerja di bidang hukum lingkungan hidup dan merupakan freelance researcher.
} 
in forestry sector. Therefore, this article will analyse whether sustainable development and environmental perspective in economics are threatened with this regulation.

Keywords: Sustainable development, environmental economy perspective, National Strategic Project, forest area.

\section{Pendahuluan}

Penerapan pembangunan berkelanjutan dan ekonomi berwawasan lingkungan dalam perekonomian nasional merupakan amanat Pasal 33 ayat (4) Undang-Undang Dasar Negara Republik Indonesia Tahun 1945 (UUD NRI 1945). Hal tersebut tersurat dari bunyi Pasal 33 ayat (4) UUD NRI 1945 yakni:

“Perekonomian nasional diselenggarakan berdasar atas demokrasi ekonomi dengan prinsip kebersamaan, efisiensi berkeadilan, berkelanjutan, berwawasan lingkungan, kemandirian, serta dengan menjaga keseimbangan kemajuan dan kesatuan ekonomi nasional ...."

Pemerintah dalam rangka pertumbuhan perekonomian nasional mela- kukan percepatan pelaksanaan Proyek Strategis Nasional (PSN). ${ }^{3}$ Penerapan pembangunan berkelanjutan dan ekonomi nasional dalam percepatan pelaksanaan PSN memerlukan pengamatan khususnya dalam hal penggunaan kawasan hutan untuk PSN yang terlihat semakin didorong di tengah pandemi COVID-19. ${ }^{4}$ Pemerintah menilai percepatan pelaksanaan PSN dapat menjaga kondisi perekonomian Indonesia yang terancam akibat COVID-19. Dorongan percepatan pelaksanaan PSN ditunjukkan dengan disahkannya Peraturan Presiden (Perpres) 66/2020 tentang Pendanaan Pengadaan Tanah bagi Pembangunan untuk Kepentingan Umum dalam Rangka Pelaksanaan PSN (Perpres 66/2020) pada awal pandemi ${ }^{5}$ yakni 19

\footnotetext{
${ }^{3}$ Komite Percepatan Penyediaan Infrastruktur Prioritas, "Proyek Strategis Nasional”, https://kppip.go.id/proyek-strategis-nasional/, diakses pada 12 Oktober 2020.

${ }^{4}$ Presiden Republik Indonesia, Joko Widodo dalam pembukaan rapat ihwal proyek strategis nasional di tengah pandemi COVID-19 melalui konferensi video pada 29 Mei 2020 sebagaimana yang dikutip oleh nasional.kompas.com, Rakhmat Nur Hakim, “Jokowi Minta PSN yang Pulihkan Ekonomi Diprioritaskan", kompas.com, 29 Mei 2020, https://nasional.kompas.com/read/2020/05/29/11093641/ jokowi-minta-psn-yang-pulihkan-ekonomi-diprioritaskan, diakses pada 7 Juli 2020.

${ }^{5}$ Marya Yenita Sitohang dkk., "Inisiatif Masyarakat Indonesia di Masa Awal Pandemi COVID-19: Sebuah Upaya Pembangunan Kesehatan", Jurnal Kependudukan Indonesia, Edisi Khusus Demografi dan COVID-19, (Juli 2020), hlm. 33-38, https://www.researchgate.net/publication/343305327_Inisiatif_ Masyarakat_Indonesia_di_Masa_Awal_Pandemi_COVID-19_Sebuah_Upaya_Pembangunan_Kesehatan, diakses pada 3 November 2020, hlm. 33. Lihat juga Haryanti Puspa dkk., "Puncak Pandemi Virus Corona RI Diprediksi Dimulai Awal Mei dengan 95 Ribu Kasus", Kompas.com, 19 April 2020, https:// www.kompas.com/tren/read/2020/04/19/152300365/puncak-pandemi-virus-corona-ri-diprediksi-dimulai-awal-mei-dengan-95-ribu, diakses pada 09 Oktober 2020.
} 
Penerapan Prinsip Pembangunan Berkelanjutan dan Ekonomi Berwawasan dalam Peraturan Perundang-Undangan Penggunaan Kawasan Hutan dalam Rangka PSN

Pasca Pengesahan Perpres 66/2020

Mei 2020. ${ }^{6}$ Ketentuan kawasan hutan sebagai salah satu objek yang akan didanai pengadaan tanahnya dalam rangka PSN berdasarkan Pasal 4 ayat (2) huruf e Perpres 66/2020 berpotensi mengancam keberlanjutan kawasan hutan. ${ }^{7}$

Perpres 66/2020 masuk ke dalam ranah hukum sektor kehutanan dengan adanya ketentuan mengenai kawasan hutan sebagai salah satu objek pengadaan tanah yang didanai. Hukum di sektor kehutanan seharusnya bersifat autentik dan selalu didasari oleh realitas kehidupan manusia dan tidak semata-mata menjadi alat yang artifisial. ${ }^{8}$ Realitas kehidupan manusia memerlukan adanya penerapan pembangunan berkelanjutan termasuk dalam ketersediaan kawasan hutan untuk generasi di masa depan. ${ }^{9}$

Pembangunan berkelanjutan merupakan kebutuhan masyarakat Indonesia yang seharusnya diterapkan dalam kebijakan pemerintah (hukum) khususnya dalam hal perekonomian nasional. ${ }^{10} \mathrm{Pe}-$ menuhan kebutuhan akan pembangunan berkelanjutan tersebut terancam tidak terpenuhi dengan sifat kebijakan Pemerintah terkait perekonomian nasional yang condong pada pembangunan ekonomi di tengah pandemi ini. Pengesahan kebijakan yang condong pada pembangunan ekonomi nasional merupakan tindakan Pemerintah dalam menanggapi ancaman kemunduran ekonomi nasional akibat pandemi. Ancaman tidak terpenuhinya kebutuhan akan pembangunan berkelanjutan dengan adanya kebijakan yang condong pada pembangunan ekonomi semata salah satunya terlihat pada kebijakan pendanaan pengadaan tanah di kawasan hutan dalam rangka pelaksanaan PSN. Kebijakan pendanaan pengadaan tanah di kawasan hutan yang termuat dalam Perpres 66/2020 menurut Lembaga Manajemen Aset Negara (LMAN) berfungsi sebagai payung hu-

\footnotetext{
${ }^{6}$ Peraturan Presiden ini mencabut Indonesia, Peraturan Presiden No. 102 Tahun 2016 tentang Pendanaan pengadaan Tanah Bagi Pembangunan Untuk Kepentingan Nasional, Perpres No. 102 Tahun 2016, LN Tahun 2016 No. 267. Hal ini diatur dalam Indonesia, Peraturan Presiden No. 66 Tahun 2020 tentang Pendanaan Pengadaan Tanah bagi Pembangunan untuk Kepentingan Umum dalam Rangka Pelaksanaan Proyek Strategis Nasional, Perpres No. 66 Tahun 2020, LN Tahun 2020 No. 135, Pasal 40.

${ }^{7}$ Hans Nicholas Jong, “Experts See Environmental, Social Fallout in Indonesia's Infrastructure Push", news.mongabay.com, https:/ / s.id/1Txfa, diakses tanggal 9 Juli 2020.

${ }^{8}$ Satjipto Raharjo, Hukum dan Perilaku: Hidup Baik adalah Dasar Hukum yang Baik, (Jakarta: PT. Kompas Media Nusantara, 2009), hlm. 9-10.

${ }^{9}$ Lihat rincian penjelasan dalam Mira Rosana, Kebijakan Pembangunan Berkelanjutan yang Berwawasan Lingkungan di Indonesia, Artikel dalam Jurnal KELOLA, Jurnal Ilmu Sosial, Vol. 1 No. 1, (2018), hlm. 154-155. https:/ / core.ac.uk/download/pdf/234031768.pdf, diakses pada 8 Oktober 2020,

${ }^{10}$ Jaka Susila, "Hukum Sebagai Paradigma Fakta Sosial, Prosiding Seminar Nasional", Pengembangan Epistemologi Ilmu Hukum, (2015), hlm. 461, https://publikasiilmiah.ums.ac.id/bitstream/handle/11617/5706/29.Jaka\%20Susila.pdf?sequence=1\&isAllowed=y, diakses pada 5 Agustus 2020.
} 
kum percepatan pendanaan pengadaan lahan PSN di tengah pandemi. ${ }^{11}$

Pasal 4 ayat (3) huruf c Perpres 3/2016 tentang Percepatan Pelaksanaan PSN (Perpres 3/2016) yang telah diubah dua kali ${ }^{12}$ mengatur untuk penggunaan kawasan hutan dalam rangka PSN dilakukan dengan Izin Pinjam Pakai Kawasan Hutan (IPPKH). Pasal 4 ayat (3) Perpres 3/2016 berbunyi sebagai berikut:

"Perizinan dan nonperizinan yang diperlukan untuk memulai pelaksanaan Proyek Strategis Nasional sebagaimana dimaksud pada ayat (1), yaitu:

a. Penetapan Lokasi;

b. Izin Lingkungan;

c. Izin Pinjam Pakai Kawasan Hutan; dan/atau

d. Izin Mendirikan Bangunan."

Berdasarkan ketentuan tersebut maka sekalipun ada pendanaan pengadaan tanah di kawasan hutan dalam rangka PSN, pelaksanaan PSN di kawasan hutan harus sesuai dengan ketentuan peraturan perundang-undangan terkait IPPKH.
Pendanaan pengadaan tanah di kawasan hutan dalam rangka PSN tidak hanya harus sesuai dengan ketentuan IPPKH sebagaimana dalam Pasal 4 ayat (3) Perpres 3/2016 namun juga harus sesuai dengan ketentuan peraturan perundang-undangan lainnya terkait pendanaan pengadaan tanah sebagaimana diatur dalam Pasal 4 ayat (3) Perpres 66/2020 tentang Pendanaan Pengadaan Tanah bagi Pembangunan untuk Kepentingan Umum dalam Rangka Pelaksanaan PSN. Hal tersebut tersurat dari Pasal 4 ayat (2) Perpres 66/2020 yang berbunyi:

“Dalam hal Pendanaan Pengadaan Tanah untuk objek Pengadaan Tanah berupa:

a. tanah instansi, berupa Barang Milik Negara/Daerah dan milik BUMN/BUMN;

b. tanah wakaf;

c. tanah kas desa;

d. aset desa; dan

e. kawasan hutan,

dilaksanakan sesuai dengan ketentuan peraturan perundang-undangan."

${ }^{11}$ Lihat Resty Woro Yuniar, “Covid-19: 'Indonesia Berpotensi Resesi' - Dampak Ekonomi 'Jauh Lebih Berat Ketimbang Krisis Moneter 1998”, https://www.bbc.com/indonesia/indonesia-53152994, diakses pada tanggal 9 Juli 2020. Lihat juga Rahma Anjaeni, "Sampai 24 Juni, LMAN telah Kucurkan Dana Rp 4,39 Triliun untuk Pembebasan Lahan", 26 Juni 2020, https://nasional.kontan.co.id/news/ sampai-24-juni-lman-telah-kucurkan-dana-rp-439-triliun-untuk-pembebasan-lahan, diakses pada 7 Juli 2020.

${ }^{12}$ Perpres ini telah mengalami beberapa perubahan yakni melalui: Indonesia, Peraturan Presiden No 58 Tahun 2017 tentang Perubahan atas Peraturan Presiden No. 3 Tahun 2016 tentang Percepatan Pelaksanaan Proyek Strategis Nasional, Perpres 58/2017, LN Tahun 2017 No. 119. Diubah lagi melalui: Indonesia, Peraturan Presiden No 56 Tahun 2018 tentang Perubahan Kedua atas Peraturan Presiden No. 3 Tahun 2016 tentang Percepatan Pelaksanaan Proyek Strategis Nasional, Perpres 56/2018, LN Tahun 2018 No. 107. 
Penerapan Prinsip Pembangunan Berkelanjutan dan Ekonomi Berwawasan dalam Peraturan Perundang-Undangan Penggunaan Kawasan Hutan dalam Rangka PSN

Pasca Pengesahan Perpres 66/2020

Kalimat “... dilaksanakan sesuai dengan ketentuan peraturan perundang-undang$a n^{\prime \prime}$ memiliki makna bahwa pelaksanaan pendanaan pengadaan tanah di kawasan hutan harus sesuai dengan peraturan perundang-undangan. Peraturan perundang-undangan terkait pendanaan pengadaan tanah di kawasan hutan selain peraturan perundang-undangan tentang pinjam pakai kawasan hutan adalah peraturan perundang-undangan tentang pengadaan tanah.

Potensi risiko keberlanjutan kawasan hutan saat aturan pendanaan pengadaan tanah masih mengacu pada Perpres 102/ 2016 tentang Pendanaan Pengadaan Tanah bagi Pembangunan untuk Kepentingan Umum dalam Rangka PSN (Perpres 102/2016) tidaklah sebesar setelah Perpres 102/2016 dicabut dan dinyatakan tidak berlaku dengan disahkannya Perpres 66/2020. Hal tersebut karena Perpres 102/2016 tidak secara spesifik mengatur kawasan hutan sebagai objek yang didanai pengadaan tanahnya dalam rangka PSN. Sedangkan, Perpres 66/2020 mengatur spesifik bahwa kawasan hutan merupakan salah satu objek yang pengadaan tanahnya didanai hingga menjadi dorongan pengadaan tanah di kawasan hutan.
Pengaturan spesifik objek-objek pengadaan tanah yang didanai dalam Perpres 66/2020 ini sesuai dengan pernyataan Presiden dalam konferensi video pada 29 Mei 2020. Presiden menyatakan bahwa pengadaan tanah/pembebasan lahan merupakan hambatan percepatan pelaksanaan PSN oleh karenanya pengesahan Perpres 66/2020 terlihat sebagai upaya Pemerintah mengurangi hambatan tersebut. ${ }^{13}$ Melihat adanya ancaman penggunaan kawasan hutan dalam rangka PSN yang "dimudahkan" dengan disahkannya Perpres 66/2020 menjadikan penulis merasa perlu untuk menganalisis penerapan prinsip pembangunan berkelanjutan dan ekonomi berwawasan lingkungan pada peraturan perundang-undangan penggunaan kawasan hutan dalam rangka percepatan PSN setelah disahkannya Perpres 66/2020 tentang Pengadaan Tanah bagi Pembangunan untuk Kepentingan Umum dalam Rangka Pelaksanaan Proyek Strategis Nasional.

Tulisan ini akan dibagi dalam beberapa bagian yang didahului dengan pendahuluan pada bagian pertama. Pada bagian kedua, tulisan ini akan membahas dua prinsip lingkungan hidup yang akan menjadi pisau analisis dalam tulisan yakni, prinsip pembangunan berkelanjutan

13 Ihsanuddin, "Jokowi: Pembebasan Lahan Jadi Hambatan Terbesar Proyek Strategis Nasional", kompas.com, 29 Mei 2020, https://nasional.kompas.com/read/2020/05/29/ 11114751 /jokowi-pembebasan-lahan-jadi-hambatan-terbesar-proyek-strategis-nasional, diakses pada 7 Juli 2020. 
dan prinsip ekonomi berwawasan lingkungan/ekonomi hijau (green economy). Selanjutnya, bagian ketiga akan menjabarkan analisis hukum mengenai ketentuan penggunaan kawasan hutan dan pengadaan tanah dengan adanya ketentuan pengadaan tanah di kawasan hutan yang didanai sebagaimana pengaturan dalam Perpres 66/2020. Kemudian, bagian keempat akan membahas analisis mengenai penerapan prinsip pembangunan berkelanjutan dan ekonomi berwawasan lingkungan/ekonomi hijau pada peraturan perundang-undangan penggunaan kawasan hutan dalam rangka PSN. Terakhir, bagian kelima akan membahas kesimpulan dari keseluruhan tulisan ini dan saran penelitian lanjutan.

\section{Prinsip Pembangunan Berkelanjut- an dan Ekonomi Berwawasan Ling- kungan di Indonesia}

\section{A. Pembangunan Berkelanjutan}

Sebelum membahas pada inti dari tulisan yakni analisis ancaman penggunaan kawasan hutan dalam rangka PSN terhadap pembangunan berkelanjutan perlu adanya pembahasan mengenai prinsip pembangunan berkelanjutan terlebih dahulu. Prinsip/konsep pembangunan berkelanjutan merupakan prinsip yang telah digagas sejak tahun 1972 dan terus berkembang dan diterapkan di kancah internasional hingga saat ini. ${ }^{14}$ Perkembangan dan penerapan prinsip pembangunan berkelanjutan ini sudah terlihat mulai dari Deklarasi Stockholm $1972^{15}$, kemudian termuat dalam Laporan Komisi Brundtland 1987, ${ }^{16}$ tercantum kembali dalam Deklarasi Rio 1992,17 di-

\footnotetext{
${ }^{14}$ Lihat pembahasannya dalam Philippe Sands, et.al, Principles of International Environmental Law: Third Edition, (Cambridge University Press, 2012), hlm. 9, 42 dan 47-49. Lihat terkait SDG pada laman International Institute for Sustainable Development (IISD), ,https://www.iisd.org/about-iisd/sustainable-development\#: :text=\%22Sustainable $\%$ 20development $\% 20$ is $\% 20$ development $\% 20$ that,to $\% 20$ meet\%20their\%20own\%20needs. \%22, diakses pada 9 Oktober 2020.

${ }^{15}$ Lihat lebih lengkapnya pada "Sustainable Development Commission United Kingdom", History of SD, http://www.sd-commission.org.uk/pages/history_sd.html, diakses pada 24 Juli 2020. Lihat juga dokumen deklarasi pada Perserikatan Bangsa-Bangsa, "Declaration of the United Nations Convention on Human Environment 1972", Deklarasi Stockholm 1972, http:/ / www.un-documents.net/aconf4814r1.pdf, diakses pada 14 Juli 2020.

${ }^{16}$ Lihat lebih lengkapnya penguraian mengenai penyampaian ini sebagai refleksi prinsip pembangunan berkelanjutan dalam Phillip Sands dan Jacqueline Peel dkk., Principles of International...Op.Cit., hlm. 206.

${ }_{17}$ Perserikatan Bangsa-Bangsa, "Report of the United Nations Conference on environment and Development: Rio Declaration on Environment and Development", Rio de Janeiro, 3-14 June 1992, Principle 1, https://www.un.org/en/development/desa/population/migration/ generalassembly/docs/globalcompact/A_CONF.151_26_Vol.I_Declaration.pdf, diakses pada 14 Juli 2020.
} 
Penerapan Prinsip Pembangunan Berkelanjutan dan Ekonomi Berwawasan dalam Peraturan Perundang-Undangan Penggunaan Kawasan Hutan dalam Rangka PSN

Pasca Pengesahan Perpres 66/2020

diskusikan dalam Konferensi Tingkat Tinggi Bumi (KTT Bumi) $2002^{18}$ hingga terbentuknya Sustainable Development Goals (SDGs) di tahun 2016. ${ }^{19}$

Konsep pembangunan berkelanjutan didiskusikan dalam Konferensi PBB di Stockholm pada tahun 1972. Komunitas internasional pada konferensi PBB di Stockholm tahun 1972 tersebut mendiskusikan konsep pembangunan berkelanjutan dan menyepakati bahwa dasar pembangunan berkelanjutan itu sendiri adalah tentang keseimbangan pembangunan dan lingkungan hidup yang mana jika dikelola dengan baik akan memberikan keuntungan yang paling efisien bagi manusia. Prinsip pembangunan berkelanjutan tersirat dalam Prinsip Ketiga dan Prinsip Kelima Deklarasi Stockholm 1972. Prinsip Ketiga dan Prinsip Kelima Deklarasi Stockholm 1972 intinya menyerukan untuk memelihara sumber daya alam dan meningkatkan 'kapasitas bumi untuk menghasilkan sumber daya yang terbarukan'.

Konsep pembangunan berkelanjutan kemudian muncul dalam Laporan Komisi Brundtland yang berjudul Our Common Future di tahun 1987. Laporan tersebut menyatakan bahwa yang dimaksud dengan pembangunan berkelanjutan adalah pembangunan yang dapat memenuhi kebutuhan saat ini namun tidak mengurangi kemampuan generasi yang akan datang untuk memenuhi kebutuhannya atas pembangunan di masa mendatang.

Prinsip pembangunan berkelanjutan kemudian dicantumkan dalam Deklarasi Rio 1992 tepatnya pada Prinsip 1, Prinsip 4, Prinsip 5, Prinsip 7- 9, Prinsip 12, Prinsip 20-22, Prinsip 24 dan Prinsip 27. Deklarasi Rio 1992 pada dasarnya berisi prinsip-prinsip yang mengharapkan negara-negara peserta menerapkan pembangunan yang selalu mempertimbangkan perlindungan lingkungan, pertumbuhan dan kondisi sosial di samping mempertimbangkan pertumbuhan ekonomi untuk mencapai pembangunan yang berkelanjutan. Deklarasi Rio 1992 meminta negara-negara untuk mengurangi hingga menghilangkan pola produksi dan konsumsi yang tidak berkelanjutan diiringi dengan pengeluaran kebijakan yang mendukung.

Di samping itu Deklarasi Rio 1992 juga menyatakan untuk negara terus menguatkan dan mengembangkan pengetahuan dan kemampuan ilmiah serta

${ }^{18}$ Report of the World Summit on Sustainable Development, Johannesburg, Afrika Selatan, 26 Agustus-4 September 2002, https:// papersmart.unon.org/resolution/uploads/2002-johannesburg_declaration-n0263693.pdf, diakses pada 14 Juli 2020. Lihat lengkapnya dalam Sustainable Development Commission United Kingdom, Loc.Cit.

${ }^{19}$ Perserikatan Bangsa-Bangsa, The Sustainable Development Goals Report 2016, https:// unstats.un.org/sdgs/report/2016/\#: :text=On\% 201\%20January \% 202016\%2C\%20the,over\%20the\%20next \% 20 15\%20years., diakses pada 4 November 2020. 
teknologi termasuk dengan cara berbagi pengetahuan antar negara dalam upaya mendukung tercapainya pembangunan berkelanjutan. Deklarasi Rio 1992 juga meminta negara-negara untuk berkerja sama tidak hanya dalam berbagi pengetahuan namun, dalam sistem koordinasi sistem ekonomi yang mendukung pertumbuhan ekonomi dan pembangunan berkelanjutan. Bahkan Deklarasi Rio 1992 juga menyatakan pentingnya keterlibatan beberapa golongan masyarakat mulai dari pentingnya peranan perempuan hingga keterlibatan kelompok masyarakat tradisional dalam pencapaian pembangunan berkelanjutan. Tidak hanya itu, Deklarasi Rio 1992 juga menyatakan pentingnya ide dari generasi muda dalam kerja sama pencapaian pembangunan berkelanjutan.

Lebih lanjut lagi setelah adanya Deklarasi Rio di tahun 1992, pada tahun 2002 diadakan Konferensi Tingkat Tinggi Bumi (World Summit on Sustainable Development) yang biasa disebut dengan KTT Bumi 2002. Prinsip pembangunan berkelanjutan pada saat KTT Bumi 2002 menjadi perhatian dunia sepenuhnya dengan hadirnya 191 negara, badan-badan PBB, institusi keuangan multilateral dan kelompok-kelompok besar lainnya. Prinsip pembangunan berkelanjutan yang telah menjadi perhatian dunia sepenuh- nya ini menjadikan setiap negara dalam melaksanakan pembangunan dilarang menyebabkan kerusakan lingkungan dan tetap dengan menjaga lingkungan hidup supaya lingkungan hidup tetap dapat memberikan manfaat bagi generasi-generasi yang akan datang.

Pembahasan prinsip pembangunan berkelanjutan dalam KTT Bumi 2002 sudah semakin mendalam dan luas. ${ }^{20}$ Pembahasan yang mendalam ini terlihat dengan dibahasnya hambatan-hambatan dalam pelaksanaan pembangunan berkelanjutan terkait: peningkatan kesejahteraan hidup masyarakat, pelaksanaan konservasi sumber daya alam di bumi dengan populasi yang terus berkembang, kebutuhan pangan, air bersih, tempat tinggal, kebersihan, energi, layanan kesehatan hingga terkait keseimbangan ekonomi.

Penerapan prinsip pembangunan berkelanjutan yang sudah semakin mantap di tingkat global menjadi semakin jelas dan terarah dengan pembentukan Sustainable Development Goals (SDGs) di tahun 2016. Pembentukan SDGs ini merupakan upaya negara-negara untuk mengimplementasikan prinsip pembangunan berkelanjutan. Implementasi/ penerapan ini dilakukan dengan adanya 2030 Agenda for Sustainable Development (Agenda 2030). Agenda 2030

\footnotetext{
${ }^{20}$ Lihat lengkapnya dalam Perserikatan bangsa-Bangsa, "World Summit on Sustainable Development (WSSD) Johannesburg Summit", Sustainable Development Goal Knowledge Platform, https:/ / sustainabledevelopment.un.org/milesstones/wssd, diakses pada 21 Juli 2020.
} 
Penerapan Prinsip Pembangunan Berkelanjutan dan Ekonomi Berwawasan dalam Peraturan Perundang-Undangan Penggunaan Kawasan Hutan dalam Rangka PSN

Pasca Pengesahan Perpres 66/2020

merupakan peta jalan untuk menjamin keberlanjutan pertumbuhan dan perkembangan sosial dan ekonomi di seluruh dunia.

Agenda 3030 tidak hanya mengatasi kemiskinan namun juga untuk mengintegrasikan dan menyeimbangkan tiga pilar pembangunan berkelanjutan dalam visi global yang komprehensif. Tiga pilar pembangunan berkelanjutan tersebut adalah pelestarian lingkungan, perkembangan sosial/masyarakat dan pertumbuhan ekonomi. Agenda 2030 ini merupakan rencana yang dapat terus berubah-ubah namun tetap dengan dasar 17 tujuan pembangunan berkelanjutan. 17 tujuan pembangunan berkelanjutan ini mengarah pada tantangan global yang mendesak dalam lima belas tahun ke depan.

Perkembangan dan penerapan prinsip pembangunan berkelanjutan di tingkat global telah Indonesia ikuti sejak Conference on the Human Environment 1972 yang melahirkan Deklarasi Stockholm 1972. ${ }^{21}$ Indonesia tidak hanya mengikuti perkembangan konsep atau prinsip pembangunan berkelanjutan namun, Indonesia juga menerapkan prinsip pembangunan berkelanjutan dalam per- aturan perundang-undangan Indonesia. Indonesia bahkan menerapkan prinsip pembangunan berkelanjutan dalam undang-undang dan peraturan pemerintah sebelum adanya Pasal 33 ayat (4) UUD NRI 1945 yang merupakan salah satu hasil amandemen keempat UUD NRI 1945 di tahun 2002. ${ }^{22}$

Indonesia telah menerapkan prinsip pembangunan berkelanjutan dalam tingkat undang-undang secara tersirat dalam UU 4/1982 tentang Ketentuan-Ketentuan Pokok Pengelolaan Lingkungan Hidup (UU 4/1982). Bagian "menimbang" huruf b UU 4/1982 berbunyi:

"bahwa untuk mendayagunakan sumber daya alam untuk memajukan kesejahteraan umum seperti termuat dalam Undang-Undang Dasar 1945 dan untuk mencapai kebahagiaan hidup berdasarkan Pancasila, perlu diusahakan pelestarian kemampuan lingkungan hidup yang serasi dan seimbang untuk menunjang pembangunan yang berkesinambungan dilaksanakan dengan kebijaksanaan terpadu dan menyeluruh serta memperhitungkan kebutuhan generasi sekarang dan mendatang;".

Indonesia sebelum amandemen keempat UUD NRI 1945 tidak hanya mene-

${ }^{21}$ Iwan J. Azis dkk., Pembangunan Berkelanjutan: Peran dan Kontribusi Emil Salim, (Jakarta: Kepustakaan Populer Gramedia, Juni 2010), https://www.researchgate.net/publication/ 256007402_Emil_Salim_Dan_Pembangunan_Berkelanjutan, diakses pada 8 Oktober 2020, hlm. 1.

${ }^{22}$ Iswara N., Raditya, Amandemen UUD 1945 Tahun 2002: Sejarah Isi \& Perubahan Keempat, tirto. id, 15 Oktober 2019, https://tirto.id/amandemen-uud-1945-tahun-2002-sejarah-isi-perubahan-keempat-ejLE, diakses pada 12 Oktober 2020. 
rapkan prinsip pembangunan berkelanjutan secara tersirat namun juga tersurat pada bagian "menimbang" huruf b UU 23/1997 tentang Pengelolaan Lingkungan Hidup (UU 23/1997) yang mencabut UU 4/1982. Bagian "menimbang" huruf b UU 23/1997 berbunyi:

"bahwa dalam rangka mendayagunakan sumber daya alam untuk memajukan kesejahteraan umum seperti diamanatkan dalam Undang-Undang Dasar 1945 dan untuk mencapai kebahagiaan hidup berdasarkan Pancasila, perlu dilaksanakan pembangunan berkelanjutan yang berwawasan lingkungan hidup berdasarkan kebijaksanaan nasional yang terpadu dan menyeluruh dengan memperhitungkan kebutuhan generasi masa kini dan generasi masa depan." lihat juga dalam Pasal 3 yang berbunyi: "Pengelolaan lingkungan hidup yang diselenggarakan dengan asas tanggung jawab nega$\mathrm{ra}$, asas berkelanjutan yang berwawasan lingkungan hidup dalam rangka pembangunan manusia Indonesia seutuhnya dan pembangunan masyarakat Indonesia seluruhnya yang beriman dan bertaqwa kepada Tuhan Yang Maha Esa."

Prinsip pembangunan berkelanjutan juga diterapkan dalam UU 32/2009 tentang Perlindungan dan Pengelolaan
Lingkungan Hidup (UU 32/2009). ${ }^{23} \mathrm{UU}$ 32/2009 merupakan peraturan induk lingkungan hidup yang masih berlaku saat ini. Prinsip pembangunan berkelanjutan dalam UU 32/2009 tersurat dalam bagian "menimbang" huruf $b$ yang berbunyi:

"bahwa pembangunan ekonomi nasional sebagaimana diamanatkan oleh Undang-Undang Dasar Negara Republik Indonesia Tahun 1945 diselenggarakan berdasarkan prinsip pembangunan berkelanjutan dan berwawasan lingkung$a n ; "$

UU 32/2009 dalam Pasal 2 huruf b juga mengatur prinsip pembangunan berkelanjutan sebagai salah satu asas perlindungan dan pengelolaan lingkungan hidup dan mengatur dalam Pasal 3 huruf i bahwa perwujudan pembangunan berkelanjutan merupakan salah satu tujuan perlindungan dan pengelolaan lingkungan hidup.

Lebih lanjut lagi, penerapan prinsip pembangunan berkelanjutan sebagai salai satu prinsip lingkungan hidup diterapkan di undang-undang kehutanan. Prinsip pembangunan berkelanjutan diterapkan dalam UU 41/1999 tentang Kehutanan(UU 41/1999). ${ }^{24}$ Undang-undang kehutanan sebelum UU 41/1999 yakni

23 Indonesia, Undang-Undang No. 32 Tahun 2009 tentang Perlindungan dan Pengelolaan Lingkungan Hidup, UU 32/2009, LN Tahun 2009 No. 140, TLN No. 5059, "Menimbang” huruf b, Pasal 1 angka 3 , Pasal 1 angka 10, pasal 3 huruf i, Pasal 15 ayat (1) dan ayat (3) dan Penjelasan bagian Umum angka 1, angka 3.

${ }^{24}$ Indonesia, Undang-Undang No. 41 Tahun 1999 tentang Kehutanan, UU 41/1999, LN Tahun 1999 
Penerapan Prinsip Pembangunan Berkelanjutan dan Ekonomi Berwawasan dalam Peraturan Perundang-Undangan Penggunaan Kawasan Hutan dalam Rangka PSN

Pasca Pengesahan Perpres 66/2020

UU 5/1967 tentang Ketentuan-Ketentuan Pokok Kehutanan (UU 5/1967) yang disahkan untuk menghadapi investasi asing di sektor kehutanan, ${ }^{25}$ belum menerapkan pembangunan berkelanjutan sehingga sumber daya kehutanan pada rezim UU 5/1967 masih cenderung dikuasai kaum elite.

Peraturan Pemerintah (PP) 21/1970 juncto PP 18/1975 tentang Hak Pengusahaan Hutan $(\mathrm{HPH})$ dan Hak Pemungutan Hasil Hutan (HPHH) serta PP 7/1990 tentang Hak Pengusahaan Tanaman Industri yang disahkan sebagai peraturan pelaksana UU 5/1967 juga belum menerapkan prinsip pembangunan berkelanjutan. Ketiadaan penerapan prinsip pembangunan berkelanjutan di peraturan perundang-undangan sektor kehutanan pada masa orde baru tersebut menyebabkan: ${ }^{26}(1)$ degradasi kuantitas dan kualitas hutan tropis di berbagai kawasan di Indonesia, (2) terbatas dan/atau hilangnya sumber-sumber kehidupan masyarakat setempat, (3) munculnya korban-korban yang semula merupakan masyarakat lokal yang tergusur akibat pembangunan dan (4) munculnya konflik-konflik atas pembangunan tersebut antara masyarakat lokal dengan pemerintah.
Bahaya eksploitasi sumber daya hutan untuk kepentingan ekonomi dan pemenuhan hak masyarakat atas hutan di masa orde baru menjadi salah satu alasan penerapan prinsip pembangunan berkelanjutan akhirnya diterapkan dalam UU 41/1999 yang mencabut UU 5/1967. ${ }^{27}$ Alasan penerapan prinsip pembangunan berkelanjutan dalam UU 41/1999 lainnya adalah dikarenakan prinsip pembangunan berkelanjutan telah masuk dalam Laporan Komisi Brundtland tahun 1987. Prinsip pembangunan berkelanjutan terdapat dalam Pasal 3 UU 41/1999 yang mengatur bahwa penyelenggaraan kehutanan bertujuan untuk sebesar-besarnya kemakmuran rakyat yang berkeadilan dan berkelanjutan yakni: (1) menjamin keberadaan hutan dengan luasan yang cukup dan sebaran yang proporsional, (2) mengoptimalkan aneka fungsi hutan (konservasi, lindung dan produksi) untuk mencapai manfaat lingkungan, sosial, budaya dan ekonomi yang seimbang dan lestari, (3) meningkatkan daya dukung daerah aliran sungai, (4) meningkatkan kemampuan untuk mengembangkan kapasitas dan keberdayaan masyarakat secara partisipatif, berkeadilan dan berwawasan lingkungan hingga mampu menciptakan

No. 167, TLN No. 3888, Bagian Menimbang huruf c, Pasal 3 dan Penjelasan bagian Umum par. 4.

${ }^{25}$ Lihat lebih lanjut pada I Nyoman Nurjaya, "Sejarah Hukum Pengelolaan Hutan di Indonesia", Jurnal Jurisprudence Vol. 2 No. 1, (Maret 2005), hlm. 35-33, https:/ / publikasiilmiah.ums.ac.id/ bitstream/ handle/11617/1036/3.NYOMANNURJAYA.pdf?sequence=1, diakses pada 23 Juli 2020., hlm. 49.

26 Ibid.

${ }^{27}$ Indonesia, Op.Cit., UU 41/1999, Pasal 83. Lihat juga Dr. I Nyoman Nurjaya, SH., M. Hum., Sejarah Hukum...Op.Cit., hlm. 49. 
ketahanan sosial, ekonomi dan perubahan eksternal dan (3) menjamin distribusi manfaat yang berkeadilan dan berkelanjutan.

Penerapan prinsip pembangunan berkelanjutan selain dalam UU 41/1999 juga dalam PP 6/1999 tentang Pengusahaan Hutan dan Pemungutan Hasil Hutan Produksi (PP 6/1999) yang merupakan peraturan pelaksana UU 41/1999 dan peraturan yang mencabut PP 21/1970 juncto PP 18/1975. Penerapan prinsip pembangunan berkelanjutan dalam PP 6/1999 terdapat dalam bagian "menimbang" huruf a yang berbunyi:

"bahwa hutan produksi di Indonesia merupakan karunia Tuhan Yang Maha Esa dan warisan kekayaan alam yang perlu dimanfaatkan secara terencana, rasional, optimal, bertanggung jawab sesuai dengan kemampuan daya dukungnya, serta dengan memperhatikan kelestarian fungsi dan keseimbangan lingkungan hidup guna mendukung pengelolaan hutan dan pembangunan kehutanan yang berkelanjutan yang diarahkan untuk sebesar-besarnya kemakmuran rakyat di masa kini dan di masa mendatang;"

\section{B. Ekonomi Berwawasan Lingkungan / Ekonomi Hijau (Green Economy)}

Pasal 33 ayat (4) UUD NRI 1945 selain mengamanatkan mengenai perekonomian nasional yang berkelanjutan (pembangunan berkelanjutan) sebagaimana yang telah dibahas di sub sebelumnya, juga mengamanatkan ekonomi nasional berwawasan lingkungan atau ekonomi hijau (green economy). Ekonomi hijau pada dasarnya adalah sebuah prinsip yang merupakan visi alternatif pelaksanaan prinsip pembangunan berkelanjutan..$^{28}$ Kedua prinsip ini tidak dapat dipisahkan karena sifat dan visi misinya yang sejalan dan searah. Pembicaraan mengenai pembangunan berkelanjutan secara tidak langsung juga mengarah pada pembicaraan mengenai ekonomi berwawasan lingkungan yang merupakan bagian dari pembangunan berkelanjutan itu sendiri. ${ }^{29}$

Ekonomi hijau mengedepankan tiga hal utama, yaitu, mempertahankan dan meningkatkan ekonomi, lingkungan, dan kehidupan sosial yang mana tiga hal tersebut sama dengan tiga pilar pembangunan berkelanjutan. ${ }^{30}$ Prinsip

${ }^{28}$ Manish Bapna dan John Talberth, "Q\&A: What is a "Green Economy"?", World Resources Institute, https://www.wri.org/blog/2011/04/qa-what-green-economy, diakses pada 21 Juli 2020.

${ }^{29}$ Lihat penjelasan lengkapnya dalam Olivia Bina, "The Green Economy and Sustainable Development: An Uneasy Balance?", Artikel dalam Environment and Planning C Government and Policy, (Desember 2013), hlm. 1023-1048, diakses pada 8 Oktober 2020, hlm. 1025.

${ }^{30}$ Manish Bapna dan John Talberth, Loc.Cit. Baca lengkapnya dalam Deputi Sumber daya Alam dan Lingkungan Hidup, "Prakarsa Strategis Pengembangan Konsep Green Economy", Badan Perencanaan Pembangunan Nasional, (Juni 2014), https://www.bappenas.go.id/files/ 6714/1170/7264/006630_buku_green_eco_ap150_2muka_17buku.pdf,diakses pada 8 Oktober 2020, hlm. 6-8, 14, 17, 18, 41 dan 43. 
Penerapan Prinsip Pembangunan Berkelanjutan dan Ekonomi Berwawasan dalam Peraturan Perundang-Undangan Penggunaan Kawasan Hutan dalam Rangka PSN

Pasca Pengesahan Perpres 66/2020

pembangunan berkelanjutan dan prinsip ekonomi hijau memiliki pilar yang sama karena prinsip ekonomi hijau ini merupakan pengembangan dari prinsip pembangunan berkelanjutan hingga perbedaan kedua prinsip ini hanya bahwa prinsip ekonomi hijau merupakan pengembangan dari prinsip pembangunan berkelanjutan. Penerapan prinsip ekonomi hijau berfungsi meningkatkan pendapatan dan mengurangi kemiskinan dengan biaya lingkungan, ekonomi, dan sosial yang signifikan dan stabil. ${ }^{31}$

Kegiatan perekonomian tanpa penerapan prinsip ekonomi hijau terbukti tidak memiliki sebuah sistem efektif. Sistem kegiatan perekonomian yang tidak menerapkan prinsip ekonomi hijau tidak mendukung keseimbangan antara apa yang diambil dari alam dan/atau risiko kegiatan perekonomian terhadap alam serta cara penanggulangannya. Bukti tidak efektifnya kegiatan perekonomian yang tidak menerapkan prinsip ekonomi hijau salah satunya adalah pelaku pembuat polusi/pencemaran tidak membayar penuh atau tidak bertanggung jawab penuh terhadap polusi/pen- cemaran yang ditimbulkannya. Ekonomi hijau oleh karenanya hadir dan mencoba mengatasi hal tersebut melalui berbagai peraturan, pajak, dan pengeluaran lainnya yang didasari oleh kebijakan ekonomi. Peran ekonomi hijau dalam produksi dan konsumsi yang berkelanjutan serta efisiensi penggunaan sumber daya alam untuk pembangunan berkelanjutan bertujuan mengurangi konsumsi, limbah, dan emisi pada setiap siklus dalam proses produksi. ${ }^{32}$

Prinsip ekonomi hijau yang berangkat dari prinsip ekonomi berwawasan lingkungan dalam Pasal 33 ayat (4) UUD NRI 1945 sama halnya dengan prinsip pembangunan berkelanjutan yakni telah diterapkan dalam peraturan perundang-undangan bahkan sebelum adanya Pasal 33 ayat (4) UUD NRI 1945 yang merupakan hasil amandemen keempat. Prinsip ekonomi berwawasan lingkungan tersurat pada bagian "menimbang" huruf b UU 23/1997. Penerapan prinsip ekonomi berwawasan lingkungan tersurat kembali dalam bagian "menimbang" huruf b UU 32/2009 yang mencabut UU 23/1997 dan masih berlaku hingga saat

31 "Poverty persists for as many as two and a halfbillion people, and the natural wealth of the planet is rapidly being drawn down. In a recent global assessment, approximately 60 percent of the world's ecosystem services were found to be degraded or used unsustainably. The gap between the rich and poor is also increasing - between 1990 and 2005, income inequality (measured by the gap between the highest and lowest income earners) rose in more than two thirds of countries.", mengutip dari Manish Bapna dan John Talberth, QEA: What is a "Green Economy", Loc.Cit..

32 United Nation Environment Program, "Green Economy", https:// ww w.unenvironment.org/regions/asia-and-pacific/regional-initiatives/ supporting-resource-efficiency/green-economy, di akses pada 21 Juli 2020. 
ini sebagai undang-undang induk lingkungan hidup termasuk untuk sektor kehutanan.

Di sektor kehutanan sendiri dalam UU 41/1999 tepatnya pada Pasal 3 huruf diatur bahwa tujuan penyelenggaraan kehutanan agar terciptanya ketahanan sosial dan ekonomi adalah salah satunya dengan meningkat kemampuan dan pengembangan kapasitas dan keberdayaan masyarakat secara berwawasan lingkungan. Penerapan prinsip ekonomi berwawasan lingkungan selain dalam peraturan perundang-undangan juga melalui Prakarsa Strategis Pengembangan Konsep Ekonomi Hijau yang dirancang oleh Deputi Sumber Daya Alam dan Lingkungan Hidup Badan Perencanaan Pembangunan Nasional (Bappenas) di tahun 2014 yang mana termasuk di dalamnya mengatur sektor kehutanan. ${ }^{33}$ Pemerintah di bidang lingkungan hidup dan kehutanan saat ini juga sedang merancang aturan ekonomi hijau rendah karbon. ${ }^{34}$ Strategi ekonomi hijau keberadaan kawasan hutan sebagaimana
Bappenas rencanakan harus dipertahankan untuk perwujudan ekonomi hijau di Indonesia.

Penerapan prinsip pembangunan berkelanjutan dan ekonomi berwawasan lingkungan/ekonomi hijau dalam UUD NRI 1945 dan penegasan penerapan prinsip pembangunan berkelanjutan dalam UU 32/2009 dan UU 41/1999 menjadikan kedua prinsip ini idealnya secara hukum juga diterapkan dalam peraturan perundang-undangan (PUU) di bawahnya termasuk pada PUU terkait penggunaan kawasan hutan dalam rangka PSN.

\section{Analisis Hukum Ketentuan Peng- gunaan Kawasan Hutan dan Penga- daan Tanah dengan Adanya Perpres $66 / 2020$}

Kawasan hutan merupakan wilayah tertentu yang ditunjuk dan/atau ditetapkan pemerintah untuk dipertahankan keberadaannya sebagai hutan tetap. ${ }^{35}$ Hutan tetap/kawasan hutan berdasarkan fungsi pokoknya terdiri dari ${ }^{36}$ kawa$41-52$.

${ }^{33}$ Lihat pada Deputi Sumber daya Alam dan Lingkungan Hidup, Prakarsa Strategis ... Op.Cit., hlm.

${ }^{34}$ Zubaedah Hanum, "Pemerintah Rancang Aturan Ekonomi Hijau Rendah Karbon", mediaindonesia.com, 5 Juli 2020, https://mediaindonesia.com/read/detail/325481-pemerintah-rancang-aturan-ekonomi-hijau-rendah-karbon, diakses pada 8 Oktober 2020.

${ }^{35}$ Indonesia, Op.Cit., Undang-Undang No. 41 Tahun 1999, Pasal 1 angka 3. Lihat juga Indonesia, Peraturan Pemerintah No. 24 Tahun 2010 tentang Penggunaan Kawasan Hutan, PP 24/2010, LN Tahun 2010 No. 30, Pasal 1 angka 2. Lihat juga pengertian hutan tetap dalam Indonesia, Peraturan Pemerintah No. 104 Tahun 2015 tentang Perubahan Peruntukan dan Fungsi Kawasan Hutan, PP 104/2015, LN Tahun 2015 No. 326, TLN No. 5794, Pasal 1 angka 12.

${ }^{36}$ Indonesia, Peraturan Pemerintah No. 6 Tahun 2007 tentang Tata Hutan dan Penyusunan Rencana Pengelolaan Hutan, serta Pemanfaatan Hutan, PP 6 / 2007, LN Tahun 2007 No. 22, TLN No. 4814, Pasal 3 ayat (2) huruf a-c. Lihat juga dalam Indonesia, Op.Cit., PP 104/2015, Pasal 1 angka 12. 
Penerapan Prinsip Pembangunan Berkelanjutan dan Ekonomi Berwawasan dalam Peraturan Perundang-Undangan Penggunaan Kawasan Hutan dalam Rangka PSN

Pasca Pengesahan Perpres 66/2020

san hutan konservasi, ${ }^{37}$ kawasan hutan lindung ${ }^{38}$ dan kawasan hutan produksi. ${ }^{39}$ Kawasan hutan konservasi memiliki ciri khas tertentu dan mempunyai fungsi pokok pengawetan keanekaragaman tumbuhan, satwa, serta ekosistemnya. Kawasan hutan lindung memiliki fungsi pokok sebagai perlindungan sistem penyangga kehidupan untuk mengatur tata air, mencegah banjir, mengendalikan erosi, mencegah intrusi air laut dan memelihara kesuburan tanah. Sedangkan Kawasan hutan produksi memiliki fungsi pokok memproduksi hasil hutan.

Penggunaan/pemanfaatan kawasan hutan untuk kegiatan di luar kegiatan kehutanan / non kehutanan hanyalah pada kawasan hutan lindung dengan pemanfaatan secara terbatas ${ }^{40}$ dan pada kawasan hutan produksi. ${ }^{41}$ Maksud dari terbatasnya pemanfaatan kawasan hutan lindung untuk kegiatan di luar kegiatan kehutanan adalah, kegiatan dalam rang- ka pemanfaatan kawasan hutan lindung hanya sebatas pinjam pakai kawasan hutan yang diperuntukkan untuk kepentingan pembangunan di luar kegiatan kehutanan. Kegiatan pembangunan di luar kegiatan kehutanan berupa penambangan di kawasan hutan lindung juga terbatas yakni hanya dapat dilakukan dengan pola pertambangan bawah tanah dan dilarang mengakibatkan turunnya permukaan tanah, mengubah fungsi pokok kawasan hutan lindung secara permanen dan merusak akuifer air tanah.

Kepentingan pembangunan di luar kegiatan kehutanan merupakan kegiatan pemanfaatan dan penggunaan kawasan hutan ${ }^{42}$ sebagai salah satu bentuk pengelolaan hutan. ${ }^{43}$ Pelaksanaan pemanfaatan kawasan hutan ini harus dengan tetap menjaga kelestarian $^{44}$ dan secara berkelanjutan. ${ }^{45}$ Pemanfaatan kawasan hutan dilakukan dengan tidak mengubah fungsi pokok kawasan hutan dan mem-

\footnotetext{
${ }^{37}$ Indonesia, Op.Cit., UU 41/1999, Pasal 1 angka 9.

${ }^{38}$ Indonesia, Op.Cit., UU 41/1999, Pasal 1 angka 8. Lihat juga dalam Indonesia, Op.Cit., PP 24/2010, Pasal 1 angka 4.

${ }^{39}$ Indonesia, Op.Cit., PP 24/2010, Pasal 1 angka 3.

${ }^{40}$ Lihat dalam Indonesia, Op.Cit., UU 41/1999, Pasal 26 dan Pasal 38 ayat (1) dan (4) juncto Indonesia, Op.Cit., PP 24/2010, Pasal 5 ayat (1) huruf b juncto Indonesia, Op.Cit., Permen LHK 7/2019, Pasal 4 ayat (1) dan Pasal 11 ayat (1) huruf b.

${ }^{41}$ Indonesia, Op.Cit., PP 24/2010, Pasal 3 ayat (1) jo. Indonesia, Op.Cit., UU 41/1999, Pasal 24. Lihat juga dalam Indonesia, Peraturan Menteri Lingkungan Hidup dan Kehutanan No. P.27/MENLHK/SETJEN/ KUM.1/7/2018 tentang Pedoman Pinjam Pakai Kawasan Hutan, Permen LHK 27/2018, BN Tahun 2018 No. 1119, Pasal 3 ayat (1) huruf a dan b.

${ }^{42}$ Indonesia, Op.Cit., UU 41/1999, Pasal 21 huruf b.

${ }^{43}$ Indonesia, Op.Cit., UU 41/1999, Pasal 10 ayat (2) huruf b.

${ }^{44}$ Indonesia, Op.Cit, UU 41/1999, Pasal 23.

${ }^{45}$ Indonesia, Op.Cit., UU 41/1999, “Menimbang” huruf c.
} 
pertimbangkan batas luas serta jangka waktu di samping mempertimbangkan kelestarian lingkungan. ${ }^{46}$

PP 61/2012 tentang Perubahan PP 24/2010 tentang Penggunaan Kawasan Hutan (PP 61/2012) mengatur bahwa penggunaan kawasan hutan lindung dan kawasan hutan produksi untuk kepentingan pembangunan di luar kegiatan kehutanan hanya dapat dilakukan untuk kegiatan bertujuan strategis yang tidak dapat dielakkan. ${ }^{47}$ Kegiatan bertujuan strategis ini adalah kegiatan yang diprioritaskan karena pengaruhnya penting secara nasional terhadap kedaulatan negara, pertahanan keamanan negara, pertumbuhan ekonomi, sosial budaya dan/atau lingkungan. Kegiatan bertujuan strategis dalam pemanfaatan kawasan hutan produksi dan kawasan hutan lindung dilakukan melalui pinjam pakai kawasan hutan dengan dasar legalitas izin pinjam pakai kawasan hutan (IPP$\mathrm{KH})^{48}$ sebagaimana yang kemudian ditegaskan kembali dalam Pasal 4 ayat (3) huruf c Perpres 3/2016 tentang Percepat- an Pelaksanaan PSN bahwa IPPKH tetap diperlukan termasuk dalam pelaksanaan PSN sebagaimana yang telah di bahas di sub pendahuluan.

Pemegang IPPKH sekaligus pelaksana PSN di kawasan hutan lindung dan/ atau kawasan hutan produksi wajib memenuhi beberapa ketentuan sebagaimana diatur dalam Pasal 15 PP 24/2010 yakni:

1. Kewajiban pemegang IPPKH memenuhi kompensasi. Kompensasi adalah salah satu kewajiban pemegang IPPKH untuk menyediakan dan menyerahkan lahan bukan kawasan hutan atau membayar sejumlah dana yang dijadikan Penerimaan Negara Bukan Pajak (PNBP) sebagai pengganti lahan kompensasi sesuai dengan ketentuan PUU atau melaksanakan penanaman dalam rangka rehabilitasi daerah aliran sungai.

2. Kewajiban pemegang IPPKH membayar Penerimaan Negara

\footnotetext{
${ }^{46}$ Indonesia, Op.Cit., PP 24/2010, Pasal 3 ayat (2). Lihat juga Indonesia, Op.Cit., Permen LHK 27/2018, Pasal 3 ayat (2).

${ }^{47}$ Indonesia, Peraturan Pemerintah No. 61 Tahun 2012 tentang Perubahan Peraturan Pemerintah No. 24 Tahun 2010 tentang Penggunaan Kawasan Hutan, PP 51/2012, LN Tahun 2012 No. 140, TLN No. 5325, Pasal 4 ayat (1). Lihat selengkapnya kegiatan di luar kegiatan kehutanan untuk kepentingan pembangunan bertujuan strategis yang tidak dapat dielakkan pada Indonesia, Peraturan Pemerintah No. 61 Tahun 2012 tentang Perubahan atas Peraturan Pemerintah No. 24 Tahun 2010 tentang Penggunaan Kawasan Hutan, PP 61/2012, LN Tahun 2012 No. 140, TLN No. 5325, Pasal 4 ayat (2) huruf a-m. Dapat dilihat juga dalam Indonesia, Peraturan Menteri Lingkungan Hidup dan Kehutanan no. P.7/MENLHK/SETJEN/KUM.1/2/2019 tentang Perubahan atas Peraturan Menteri Lingkungan Hidup dan Kehutanan Nomor P.27/MENLHK/SETJEN/KUM.1/7/2018 tentang Pedoman Pinjam Pakai Kawasan Hutan, Permen LHK 7/2019, BN Tahun 2019 No. 462, Pasal 4.

${ }^{48}$ Indonesia, Op.Cit., PP 24/2010, Pasal 6 ayat (1). Lihat juga dalam Indonesia, Op.Cit., Permen LHK 7/2019, Pasal 5.
} 
Penerapan Prinsip Pembangunan Berkelanjutan dan Ekonomi Berwawasan dalam Peraturan Perundang-Undangan Penggunaan Kawasan Hutan dalam Rangka PSN

Pasca Pengesahan Perpres 66/2020

Bukan Pajak Penggunaan Kawasan Hutan. PNBP Penggunaan Kawasan Hutan ini tidak sama dengan dana PNBP yang merupakan alternatif kewajiban kompensasi.

3. Kewajiban pemegang IPPKH melakukan penanaman dalam rangka rehabilitasi daerah aliran sungai.

4. Kewajiban pemegang IPPKH melakukan reboisasi pada lahan kompensasi.

5. Kewajiban pemegang IPPKH untuk melindungi hutan. ${ }^{49}$ Makna hutan di sini luas tidak sebatas makna kawasan hutan. Makna hutan yang dimaksud adalah hutan sebagai satu kesatuan ekosistem berupa hamparan lahan berisi sumber daya alam hayati yang didominasi pepohonan dalam persekutuan alam lingkungannya yang satu dengan lainnya tidak dapat dipisahkan.

6. Kewajiban pemegang IPPKH melaksanakan reklamasi dan/atau reboisasi pada kawasan hutan bekas pinjam pakai yang sudah tidak digunakan.

Pemegang IPPKH tidak hanya terikat enam kewajiban tersebut namun juga terikat untuk melaksanakan kewajiban lainnya yang diatur dalam Pasal 42-44 Peraturan Menteri Lingkungan Hidup dan Kehutanan (Permen LHK) 27/2018 tentang Pedoman Pinjam Pakai Kawasan Hutan (Permen LHK 27/2018). ${ }^{50}$

Kewajiban memiliki IPPKH untuk berkegiatan di luar kegiatan kehutanan dalam kawasan hutan produksi dan kawasan hutan lindung tidak hanya diatur dalam Permen LHK 27/2018 jo. Permen LHK 7/2019 namun, Perpres 3/ 2016 tentang Percepatan Pelaksanaan PSN juga mengatur pelaksanaan PSN di kawasan hutan dilakukan dengan pinjam pakai kawasan hutan. Hal tersebut dikarenakan Pasal 4 ayat (3) huruf c Perpres 3/2016 mengatur bahwa menteri atau kepala lembaga selaku penanggung jawab PSN mengajukan penyelesaian perizinan salah satunya IPPKH karena izin ini diperlukan untuk memulai pelaksanaan PSN.

Hal yang melatarbelakangi pembuatan tulisan ini adalah ancaman "kemudahan" penggunaan kawasan hutan dalam rangka percepatan pelaksanaan PSN dengan adanya ketentuan pengadaan tanah di kawasan hutan yang didanai dalam Perpres 66/2020 tentang Pendanaan Pengadaan Tanah bagi Pembangunan untuk Kepentingan Umum. Pasal 4 ayat

\footnotetext{
${ }^{49}$ Hal ini berdasarkan ketentuan dalam Indonesia, Op.Cit., UU 41/1999, Pasal 1 angka 2. Kewajiban melindungi hutan diatur dalam Indonesia, Op.Cit., PP 24/2010, Pasal 15 huruf d.

${ }^{50}$ Indonesia, Op.Cit., PP 24/2010, Pasal 15 huruf f. Indonesia, Op.Cit., Permen LHK 27/2018 juncto Indonesia, Op.Cit., Permen LHK 7/2019.
} 
(2) huruf e Perpres 66/2020 mengatur bahwa objek pengadaan tanah yang didanai salah satunya berupa kawasan hutan yang pelaksanaannya dilaksanakan sesuai dengan ketentuan PUU yang itu berarti harus dilaksanakan sesuai dengan PUU terkait penggunaan kawasan hutan dan pengadaan tanah sebagaimana yang telah dibahas dalam sub pendahuluan.

Pengadaan tanah untuk pelaksanaan PSN mengacu pada UU 2/2012 tentang Pengadaan Tanah bagi Pembangunan untuk Kepentingan Umum (UU 2/2012) dan Perpres 71/2012 tentang Penyelenggaraan Pengadaan Tanah bagi Pembangunan untuk Kepentingan Umum yang telah diubah empat kali. ${ }^{51}$ Pengadaan tanah adalah kegiatan menyediakan tanah dengan cara memberi ganti kerugian yang layak dan adil kepada pihak yang berhak. ${ }^{52}$ Maksud kepentingan umum di sini adalah kepentingan bangsa, negara dan masyarakat yang harus diwujudkan oleh pemerintah dan digunakan sebesar- besarnya untuk kemakmuran rakyat..$^{53}$ Pengadaan tanah untuk kepentingan umum diselenggarakan pemerintah ${ }^{54}$ dengan jaminan dana juga dari pemerintah. ${ }^{55}$

Objek pengadaan tanah dalam Pasal 1 angka 4 UU 2/2012 adalah tanah, ruang atas tanah dan bawah tanah, bangunan, tanaman, benda yang berkaitan dengan tanah atau lainnya yang dapat dinilai. UU 2/2012 tidak mengatur spesifik kawasan hutan sebagai objek pengadaan tanah. Melihat definisi objek pengadaan tanah, kawasan hutan dapat saja menjadi yang dimaksud sebagai objek pengadaan tanah karena luasnya definisi objek pengadaan tanah dalam UU 2/2012. Luasnya definisi objek pengadaan tanah dalam UU 2/ 2012 tidak menjadikan pengadaan tanah dapat serta-merta begitu saja dilakukan di kawasan hutan sekalipun dalam rangka PSN tanpa mementingkan keberlanjutan kawasan hutan.

\footnotetext{
${ }^{51}$ Indonesia, Peraturan Presiden No. 40 tahun 2014 tentang Perubahan atas Peraturan Presiden Nomor 71 Tahun 2012 tentang Penyelenggaraan Pengadaan Tanah bagi Pembangunan untuk Kepentingan Umum, Perpres 71/2014, LN Tahun 2014 No. 94, "Menimbang" huruf b. Diubah kemudian melalui Indonesia, Peraturan Presiden No. 99 Tahun 2014 tentang Perubahan Kedua atas Peraturan Presiden No. 71 Tahun 2012 tentang penyelenggaraan Pengadaan Tanah bagi Pembangunan untuk Kepentingan Umum, Perpres 99/2014, LN Tahun 2014 No. 223, Menimbang huruf b. Diubah kemudian melalui Indonesia, Peraturan Presiden No. 30 Tahun 2015 tentang Perubahan Ketiga atas Peraturan Presiden No. 71 Tahun 2012 tentang Penyelenggaraan Pengadaan Tanah bagi Pembangunan untuk Kepentingan Umum, UU 71/2012, LN Tahun 2015 No. 55. Diubah kemudian melalui Indonesia, Peraturan Presiden No. 148 Tahun 2015 tentang Perubahan Keempat atas Peraturan Presiden No. 71 Tahun 2012 tentang Penyelenggaraan Pengadaan Tanah bagi Pembangunan untuk Kepentingan Umum, Perpres 148/2015, LN Tahun 2015 No. 366.

${ }^{52}$ Indonesia, Undang-Undang No. 2 Tahun 2012 tentang Pengadaan Tanah bagi Pembangunan untuk Kepentingan Umum, UU 2/2012, LN Tahun 2012 No. 22, TLN No. 5280, Pasal 1 angka 2.

${ }^{53}$ Indonesia, Op.Cit., UU 2/2012, Pasal 1 angka 6. Lihat juga Indonesia, Op.Cit., Perpres 4/2014

${ }^{54}$ Indonesia, Op.Cit., UU 2/2012, Pasal 6.

${ }^{55}$ Indonesia, Op.Cit., UU 2/2012, Pasal 4 ayat (1) dan ayat (2).
} 
Penerapan Prinsip Pembangunan Berkelanjutan dan Ekonomi Berwawasan dalam Peraturan Perundang-Undangan Penggunaan Kawasan Hutan dalam Rangka PSN

Pasca Pengesahan Perpres 66/2020

Pentingnya memperhatikan keberlanjutan kawasan hutan dalam pelaksanaan PSN di kawasan hutan adalah dikarenakan pengguna kawasan hutan dalam rangka PSN tetap wajib memiliki IPPKH di samping kewajiban memberi ganti kerugian yang layak dan adil kepada pihak yang berhak dalam hal pengadaan tanah. ${ }^{56}$ Pemegang IPPKH terikat berbagai kewajiban dan syarat kepemilikan IPPKH yang diatur dalam Pasal 9-15 PP 24/2010 jo. PP 61/2012 tentang Penggunaan Kawasan Hutan dan Pasal 21-44 Permen LHK 27/2018 jo. Permen LHK 7/2019 tentang Pedoman Pinjam Pakai Kawasan Hutan.

Berdasarkan analisis hukum Penulis ancaman penggunaan kawasan hutan dalam rangka PSN yang timbul karena ketentuan Pasal 4 ayat (2) huruf e Perpres 66/2020 berkurang dengan adanya ketentuan kewajiban memiliki IPPKH untuk melaksanakan PSN di kawasan hutan dan adanya kewajiban memberi ganti kerugian yang layak dan adil kepada pihak yang berhak dalam hal pengadaan tanah. Ketentuan mengenai IPPKH dalam PP 24/2010 jo. PP 61/2012 dan Permen LHK 27/2018 jo. Permen LHK 7/2019 telah diatur sedemikian rupa supaya penggunaan kawasan hutan tetap dilaksanakan dengan tetap menjaga kelestarian lingkungan sekalipun dalam rangka PSN. Analisis hukum selanjutnya yang perlu dilakukan adalah mengenai penerapan prinsip pembangunan berkelanjutan dan ekonomi berwawasan lingkungan dalam ketentuan penggunaan kawasan hutan dalam rangka PSN.

\section{Analisis Hukum Penerapan Prinsip} Pembangunan Berkelanjutan dan Ekonomi Berwawasan Lingkungan / Ekonomi Hijau pada Peraturan Perundang-Undangan Penggunaan Kawasan Hutan dalam Rangka PSN

Prinsip pembangunan berkelanjutan dan ekonomi berwawasan lingkungan yang tidak terpisahkan dengan prinsip pembangunan berkelanjutan seharusnya tercermin dalam peraturan perundang-undangan terkait pemanfaatan kawasan hutan dalam rangka PSN karena merupakan amanat Pasal 33 ayat (4) UUD NRI 1945 dan Pasal 3 UU 41/1999 tentang Kehutanan. Penulis melakukan analisis penerapan prinsip pembangunan berkelanjutan dan ekonomi berwawasan lingkungan/ekonomi hijau pada peraturan perundang-undangan penggunaan kawasan hutan dalam rangka PSN dengan melihat pada aturan kewajiban pemegang Izin Pinjam Pakai Kawasan Hutan (IPPKH). Kewajiban pemegang IPPKH ini diatur dalam Pasal 15 PP 24/2010 jo. Pasal 42 Permen LHK 27/2018. Alasan Penulis melihat pada aturan hukum kewajiban pemegang IPPKH karena seka-

${ }^{56}$ Indonesia, Op.Cit., UU 2/2012, Pasal 5, Pasal 8, Pasal 12 ayat (1) Pasal 50 dan Pasal 56. 
lipun kawasan hutan digunakan dalam rangka pelaksanaan PSN, pelaksana PSN tetap wajib memiliki IPPKH. Kewajiban pemegang IPPKH sebagaimana diatur dalam Pasal 15 PP 24/2010 juncto Pasal 42 Permen LHK 27/ 2018 adalah sebagai berikut:

1. Kewajiban menyelesaikan tata batas lahan, menyediakan dan reboisasi lahan kompensasi,

2. Reklamasi dan revegetasi kawasan hutan yang sudah tidak dipergunakan setelah digunakan,

3. Penanaman dalam rangka rehabilitasi daerah aliran sungai,

4. Penanaman pohon jenis unggulan setempat di areal IPPKH,

5. Melaksanakan inventarisasi tegakan sesuai dengan rencana kerja penggunaan kawasan hutan tahunan dan membayar tegakan jika areal yang dimohonkan merupakan hutan tanaman hasil rehabilitasi,

6. Memelihara batas areal IPPKH,

7. Melaksanakan perlindungan hutan areal IPPKH,

8. Melakukan pencegahan dan perlindungan kebakaran hutan dan lahan,

9. Mengamankan Kawasan Hutan Konservasi dan Lindung yang berbatasan dengan areal IPPKH,

10. Memberi kemudahan aparat berwenang melakukan monitoring dan evaluasi,

11. Mengoordinasikan kegiatan kepada instansi lingkungan hidup dan kehutanan dan/atau pemegang izin pemanfaatan atau pengelolaan hutan,

12. Pemberdayaan masyarakat sekitar areal IPPKH,

13. Melapor secara berkala kepada Menteri Lingkungan Hidup dan Kehutanan atas penggunaan kawasan hutan yang dipinjam pakai,

14. Melakukan pembayaran Penerimaan Negara Bukan Pajak (PNBP), Provisi Sumber Daya Hutan (PSDH) dan Dana Reboisasi (DR) serta mengganti biaya investasi pengelolaan hutan kepada pemegang izin usaha pemanfaatan hasil hutan jika IPPKH dalam areal kerja pengelolaan hutan.

Kewajiban yang harus dipenuhi pemegang IPPKH sebagaimana telah tersebut di atas untuk dapat dikatakan menerapkan pembangunan berkelanjutan dan ekonomi hijau harus mencerminkan/ sesuai dengan tiga pilar pembangunan berkelanjutan dan ekonomi berwawasan lingkungan. Tiga pilar ini yakni pelestarian lingkungan, perkembangan sosial dan pertumbuhan ekonomi harus terintegrasi untuk terwujudnya pembangun- 
Penerapan Prinsip Pembangunan Berkelanjutan dan Ekonomi Berwawasan dalam Peraturan Perundang-Undangan Penggunaan Kawasan Hutan dalam Rangka PSN

Pasca Pengesahan Perpres 66/2020

an yang berkelanjutan dan ekonomi hijau. ${ }^{57}$

Makna pelestarian lingkungan adalah bahwa pelestarian lingkungan ini harus ada dalam aspek perkembangan sosial dan pertumbuhan ekonomi karena ketersediaan lingkungan hidup dan sumber daya alam harus terjaga untuk generasi kini dan masa depan. Perkembangan sosial artinya kebutuhan dasar manusia terpenuhi dari penerapan dan realisasi hak asasi manusia. Sedangkan pertumbuhan ekonomi diartikan sebagai ketersediaan lapangan kerja dan kemampuan tiap individu untuk memiliki pendapatan yang mencukupi untuk dirinya dan keluarganya.

Pilar pelestarian lingkungan dan perkembangan masyarakat tercermin dari kewajiban-kewajiban pemegang Izin Pinjam Pakai Kawasan Hutan (IPPKH) dalam Pasal 15 PP 24/2010 juncto Pasal 42 Permen LHK 27/2018. Sedangkan pilar pertumbuhan ekonomi tercermin dari penggunaan kawasan hutan dalam rangka PSN bertujuan untuk peningkatan pertumbuhan ekonomi nasional. ${ }^{58}$ Tiga pilar pembangunan berkelanjutan dan ekonomi hijau setelah Penulis analisis tercermin dari poin-poin kewajiban pemegang IPPKH dan tujuan daripada PSN itu sendiri.

Pelaksana PSN di kawasan hutan wajib memiliki IPPKH demikian terikat dengan kewajiban pemegang IPPKH yang diatur dalam peraturan perundang-undangan. Tiga pilar pembangunan berkelanjutan dan ekonomi hijau sebagaimana hasil analisis Penulis ternyata terpenuhi/diterapkan dalam aturan kewajiban pemegang IPPKH dan tujuan dari PSN. Hasil analisis ini menunjukkan bahwa Indonesia telah berupaya secara hukum melalui peraturan perundang-undangan untuk mewujudkan keseimbangan antara pelestarian lingkungan, pemberdayaan masyarakat, dan pertumbuhan ekonomi sekalipun dalam pelaksanaan PSN. Hasil analisis ini juga menujukkan bahwa ancaman kemudahan penggunaan kawasan hutan dengan adanya ketentuan pendanaan pengadaan tanah objek kawasan hutan walaupun tidak sepenuhnya teratasi namun tereduksi/berkurang dengan adanya kewajiban memiliki IPPKH beserta pemenuhan kewajiban pemegang IPPKH yang

\footnotetext{
57 A. Seilan, "Sustainable Development: The Balance between Conserving Environmental Resources and Economic Development", Penelitian yang disampaikan dalam Seminar Nasional: Climate Change, Environment and Agricultural Development, diselenggarakandiDepartmentofEnvironmentalEconomicSchoolofEconomics,MaduraiKamarajUniversity, Madurai, (27-28 Maret 2014), https://www.researchgate.net/publication/340088070_Sustainable Development_The_Balance_between_Conserving_Environmental_Resources_and_Economic_Development, diakses pada 9 Oktober 2020, hlm. 2-4. Lihat juga terkait ekonomi berwawasan lingkungan dalam Manish Bapna dan John Talberth, QEA: What is a "Green Economy", Loc.Cit..

${ }^{58}$ Komite Percepatan Penyediaan Infrastruktur Prioritas, Proyek ...Loc.Cit..
} 
mana kewajiban-kewajiban tersebut telah menerapkan prinsip pembangunan berkelanjutan dan ekonomi hijau.

\section{Penutup}

Ancaman "kemudahan" penggunaan kawasan hutan dalam rangka PSN karena adanya ketentuan didanai nya pengadaan tanah di kawasan hutan dalam Perpres 66/2020 terkurangi dengan adanya kewajiban pelaksana PSN untuk taat pada ketentuan terkait pinjam pakai kawasan hutan dan pengadaan tanah. Pelaksana PSN di kawasan hutan harus memiliki Izin Pinjam Pakai Kawasan Hutan (IPPKH) sekaligus memenuhi kewajiban pemegang IPPKH. Aturan mengenai kewajiban-kewajiban yang harus dipenuhi oleh pemegang IPPKH dalam peraturan perundang-undangan telah menerapkan prinsip pembangunan berkelanjutan dan ekonomi hijau karena aspek pelestarian lingkungan, perkembangan sosial dan pertumbuhan ekonomi yang merupakan tiga pilar prinsip pembangunan berkelanjutan dan ekonomi hijau/ekonomi berwawasan lingkungan tercermin dalam poin-poin kewajiban pemegang IP$\mathrm{PKH}$. Oleh karena itu, Indonesia dapat dikatakan telah berupaya secara hukum menerapkan prinsip pembangunan berkelanjutan dan ekonomi berwawasan lingkungan/ekonomi hijau dalam pelaksanaan PSN di kawasan hutan melalui ketentuan dalam peraturan perundang-undangan. Penelitian lebih lanjut dapat dilakukan untuk mengetahui realita penerapan prinsip pembangunan berkelanjutan dan ekonomi hijau dalam praktiknya di lapangan. 
Penerapan Prinsip Pembangunan Berkelanjutan dan Ekonomi Berwawasan dalam Peraturan Perundang-Undangan Penggunaan Kawasan Hutan dalam Rangka PSN

Pasca Pengesahan Perpres 66/2020

\section{DAFTAR PUSTAKA}

\section{Peraturan Perundang-Undangan}

Indonesia. Undang-Undang Dasar Negara

Republik Indonesia Tahun 1945, UUD

NRI 1945, Amandemen Keempat.

- Undang-Undang No. 4 Tahun

1982 tentang Ketentuan-Ketentuan Po-

kok Pengelolaan Lingkungan Hidup, UU

No. 4 Tahun 1982, LN Tahun 1982

No. 12, TLN 3215.

. Undang-Undang No. 23 Tahun

1997 tentang Pengelolaan Lingkungan

Hidup, UU No. 23 Tahun 1997, LN

Tahun 1997 No. 68, TLN No. 3699.

Undang-Undang No. 41 Tahun

1999 tentang Kehutanan, UU 41/1999,

LN Tahun 1999 No. 167, TLN No. 3888 .

Undang-Undang No. 32 Tahun

2009 tentang Perlindungan dan Pengelolaan Lingkungan Hidup, UU 32/2009, LN Tahun 2009 No. 140, TLN No. 5059.

Undang-Undang No. 2 Tahun

2012 tentang Pengadaan Tanah bagi Pembangunan untuk Kepentingan Umum, UU 2/2012, LN Tahun 2012 No. 22, TLN No. 5280.

Peraturan Pemerintah No. 21 Tahun 1970 tentang Hak Pengusahaan Hutan dan Hak Pemungutan Hasil Hutan, PP 21/1970, LN Tahun 1970 No. 31, TLN No. 2935.

Peraturan Pemerintah No. 19 Tahun 1975 tentang Perubahan Peraturan Pemerintah No. 21 Tahun 1970 tentang Hak Pengusahaan Hutan dan Hak Pe- mungutan Hasil Hutan, PP 19/1975, LN Tahun 1975 No. 22, TLN No. 3055. . Peraturan Pemerintah No. 6 Tahun 1999 tentang Pengusahaan Hutan dan Pemungutan Hasil Hutan pada Hutan Produksi, PP 6/1999, LN Tahun 1999 No. 13, TLN No. 3802.

- Peraturan Pemerintah No. 6 Tahun 2007 tentang Tata Hutan dan Penyusunan Rencana Pengelolaan Hutan, serta Pemanfaatan Hutan, PP 6 / 2007, LN Tahun 2007 No. 22, TLN No. 4814.

. Peraturan Pemerintah No. 24 Tahun 2010 tentang Penggunaan Kawasan Hutan, PP 24/2010, LN Tahun 2010 No. 30.

- Peraturan Pemerintah No. 61 Tahun 2012 tentang Perubahan Peraturan Pemerintah No. 24 Tahun 2010 tentang Penggunaan Kawasan Hutan, PP 51/2012, LN Tahun 2012 No. 140, TLN No. 5325.

- Peraturan Pemerintah No. 104 Tahun 2015 tentang Perubahan Peruntukan dan Fungsi Kawasan Hutan, PP 104/2015, LN Tahun 2015 No. 326, TLN No. 5794.

. Peraturan Presiden No. 40 tahun 2014 tentang Perubahan atas Peraturan Presiden Nomor 71 Tahun 2012 tentang Penyelenggaraan Pengadaan Tanah bagi Pembangunan untuk Kepentingan Umum, Perpres 71/2014, LN Tahun 2014 No. 94.

. Peraturan Presiden No. 99 Tahun 2014 tentang Perubahan Kedua atas Per- 
aturan Presiden No. 71 Tahun 2012 tentang penyelenggaraan Pengadaan Tanah bagi Pembangunan untuk Kepentingan Umum, Perpres 99/2014, LN Tahun 2014 No. 223.

. Peraturan Presiden No. 30 Tahun 2015 tentang Perubahan Ketiga atas Peraturan Presiden No. 71 Tahun 2012 tentang Penyelenggaraan Pengadaan Tanah bagi Pembangunan untuk Kepentingan Umum, UU 71/2012, LN Tahun 2015 No. 55.

Peraturan Presiden No. 148 Tahun 2015 tentang Perubahan Keempat atas Peraturan Presiden No. 71 Tahun 2012 tentang Penyelenggaraan Pengadaan Tanah bagi Pembangunan untuk Kepentingan Umum, Perpres 148/2015, LN Tahun 2015 No. 366.

. Peraturan Presiden No. 3 Tahun 2016 tentang Percepatan Pelaksanaan Proyek Strategis Nasional, Perpres 3/2016, LN Tahun 2016, No. 4.

. Peraturan Presiden No. 102 Tahun 2016 tentang Pendanaan pengadaan Tanah Bagi Pembangunan Untuk Kepentingan Nasional, Perpres No. 102 Tahun 2016, LN Tahun 2016 No. 267.

. Peraturan Presiden No 58 Tahun 2017 tentang Perubahan atas Peraturan Presiden No. 3 Tahun 2016 tentang Percepatan Pelaksanaan Proyek Strategis Nasional, Perpres 58/2017, LN Tahun 2017 No. 119.

. Peraturan Presiden No 56 Tahun 2018 tentang Perubahan Kedua atas Peraturan Presiden No. 3 Tahun 2016 tentang Percepatan Pelaksanaan Proyek
Strategis Nasional, Perpres 56/2018, LN Tahun 2018 No. 107.

Peraturan Menteri Lingkungan Hidup dan Kehutanan No. P.27/MENLHK/SETJEN/KUM.1/7/2018 tentang Pedoman Pinjam Pakai Kawasan Hutan, Permen LHK 27/2018, BN Tahun 2018 No. 1119.

. Peraturan Menteri Lingkungan Hidup dan Kehutanan no. P.7/MENLHK/ SETJEN/KUM.1/2/2019 tentang Perubahan atas Peraturan Menteri Lingkungan Hidup dan Kehutanan Nomor P.27/ MENLHK/SETJEN/KUM.1/7/2018 tentang Pedoman Pinjam Pakai Kawasan Hutan, Permen LHK 7/2019, BN Tahun 2019 No. 462.

Peraturan Presiden No. 66 Tahun 2020 tentang Pendanaan Pengadaan Tanah bagi Pembangunan untuk Kepentingan Umum dalam Rangka Pelaksanaan Proyek Strategis Nasional, Perpres No. 66 Tahun 2020, LN Tahun 2020 No. 135.

\section{Dokumen Internasional}

Bangsa-Bangsa, Perserikatan. Report of the United Nations Conference on environment and Development: Rio Declaration on Environment and Development, Rio de Janeiro, 3-14 June 1992, Principle 1, https://www.un.org/ en/development/desa/population/ migration/generalassembly/docs/ globalcompact/A_CONF.151_26_ Vol.I_Declaration.pdf, diakses pada 14 Juli 2020.

- Declaration of the United Nations Convention on Human Environ- 
Penerapan Prinsip Pembangunan Berkelanjutan dan Ekonomi Berwawasan dalam Peraturan Perundang-Undangan Penggunaan Kawasan Hutan dalam Rangka PSN

Pasca Pengesahan Perpres 66/2020

ment 1972, Deklarasi Stockholm 1972, http://www.un-documents.net/ aconf48-14r1.pdf, diakses pada 14 Juli 2020.

Declaration of the United Nations Convention on Human Environment 1972, Deklarasi Stockholm 1972, http://www.un-documents.net/ aconf48-14r1.pdf, diakses pada 14 Juli 2020.

\section{Buku}

Azis, Iwan J. dkk. Pembangunan Berkelanjutan: Peran dan Kontribusi Emil Salim, Kepustakaan Populer Gramedia, Jakarta, Juni 2010, ISBN: 978-979-910258-4, https://www.researchgate. net/publication/256007402_Emil_ Salim_Dan_Pembangunan_Berkelanjutan, diakses pada 8 Oktober 2020.

Bangsa-Bangsa, Perserikatan. Economic and Social Survey of Asia and the Pacific 2015 - Part II - Balancing the Three Dimensions of Sustainable Development: From Integration to Implementation, United Nations: Economic and Social Commission for Asia and the Pacific, 2015, e-ISBN: 978-92-1-0573740, https://www.unescap.org/sites/ default/files/publications/survey2015-pt2-cs71-theme-study.pdf, diakses pada 9 Oktober 2020.

Hidup, Deputi Sumber daya Alam dan Lingkungan. Prakarsa Strategis Pengembangan Konsep Green Economy, Badan Perencanaan Pembangunan Nasional, Juni 2014, https://www.bappenas.go.id/files $\angle 6714 / 1170 / 7264 / 006630$ buku green_eco_ap150_2muka_17buku. pdf, diakses pada 8 Oktober 2020.

Raharjo, Satjipto. Hukum dan Perilaku: Hidup Baik adalah Dasar Hukum yang Baik, Jakarta, PT. Kompas Media Nusantara, 2009.

Sands, Phillippe dan Jacqueline Peel dkk. Principles of International Environmental Law, Third Edition, Cambridge University Press, United Kingdom, 2012, ISBN: 978-0-521-76959-4.

\section{Artikel Jurnal / Media Massa}

Anjaeni, Rahma. Sampai 24 Juni, LMAN telah Kucurkan Dana $R p$ 4,39 Triliun untuk Pembebasan Lahan, 26 Juni 2020, https://nasional.kontan.co.id/ news/sampai-24-juni-lman-telah-kucurkan-dana-rp-439-triliun-untuk-pembebasan-lahan, diakses pada 7 Juli 2020.

Bina, Olivia. The Green Economy and Sustainable Development: An Uneasy Balance?", Artikel dalam Environment and Planning C Government and Policy, Desember 2013, hlm. 1023-1048, e-ISSN: 23996544, https://www.researchgate. net/publication/259570713_The_ green_economy_and_sustainable_ development_An_uneasy_balance, diakses pada 8 Oktober 2020.

Hakim, Rakhmat Nur. Jokowi Minta PSN yang Pulihkan Ekonomi Diprioritaskan, kompas.com, 29 Mei 2020, https:// nasional.kompas.com/read/2020/ 05/29/11093641/jokowi-minta-psn- 
-yang-pulihkan-ekonomi-diprioritaskan, diakses pada 7 Juli 2020.

Hanum, Zubaedah. Pemerintah Rancang Aturan Ekonomi Hujau Rendah Karbon, Humaniora: mediaindonesia.com, 5 Juli 2020, https:// mediaindonesia.com/read/detail/ 325481-pemerintah-rancang-aturan-ekonomi-hijau-rendah-karbon, diakses pada 8 Oktober 2020.

Ihsanuddin. Jokowi: Pembebasan Lahan Jadi Hambatan Terbesar Proyek Strategis Nasional, kompas.com, 29 Mei 2020, https://nasional.kompas.com/ read/2020/05/29/11114751/jokowi-pembebasan-lahan-jadi-hambatan-terbesar-proyek-strategis-nasional, diakses pada 7 Juli 2020.

Jong, Hans Nicholas. Experts See Environmental, Social Fallout in Indonesia's Infrastructure Push, news.mongabay. com, https://s.id/lTxfa, diakses tanggal 9 Juli 2020.

Nurjaya, I Nyoman, Dr. SH., M.Hum., Sejarah Hukum Pengelolaan Hutan di Indonesia, Jurnal Jurisprudence Vol. 2 No. 1, Maret 2005, hlm. 35-33, https:// publikasiilmiah.ums.ac.id/bitstream/handle/11617/1036/3.NYOMANNURJAYA.pdf? sequence $=1$, diakses pada 23 Juli 2020.

Puspa, Haryanti dkk. Puncak Pandemi Virus Corona RI Diprediksi Dimulai Awal Mei dengan 95 Ribu Kasus, Kompas.com, 19 April 2020, https://www.kompas.com/tren/ $\mathrm{read} / 2020 / 04 / 19 / 152300365 /$ puncak-pandemi-virus-corona-ri-dip- rediksi-dimulai-awal-mei-dengan-95-ribu, diakses pada 09 Oktober 2020.

Raditya, Iswara N. Amandemen UUD 1945 Tahun 2002: Sejarah Isi \& Perubahan Keempat, tirto.id, 15 Oktober 2019, https://tirto.id/amandemen-uud-1945-tahun-2002-sejarah-isi-perubahan-keempat-ejLE, diakses pada 12 Oktober 2020.

Rosana, Mira. Kebijakan Pembangunan Berkelanjutan yang Berwawasan Lingkungan di Indonesia, Artikel dalam Jurnal KELOLA, Jurnal Ilmu Sosial Vol. 1 No. 1, 2018, hlm. 148-163, e-ISSN: 2622-6103, https://core.ac.uk/download/pdf/234031768.pdf, diakses pada 8 Oktober 2020.

Seilan, A., Dr. Sustainable Development: The Balance between Conserving Environmental Resources and Economic Development, Penelitian yang dipresentasikan dalam Seminar Nasional: Climate Change, Environment and Agricultural Development, diselenggarakan di Department of Environmental Economic School of Economics, Madurai Kamaraj University, Madurai, 27-28 Maret 2014, https://www.researchgate.net/publication/340088070_Sustainable_Development_The_Balance_between_ Conserving_Environmental_Resources_and_Economic_Development, diakses pada 9 Oktober 2020.

Sitohang, Marya Yenita dkk. Inisiatif Masyarakat IndonesiadiMasa Awal Pandemi COVID-19: Sebuah Upaya Pembangunan Kesehatan, Jurnal Kependudukan 
Penerapan Prinsip Pembangunan Berkelanjutan dan Ekonomi Berwawasan dalam Peraturan Perundang-Undangan Penggunaan Kawasan Hutan dalam Rangka PSN

Pasca Pengesahan Perpres 66/2020

Indonesia, Edisi Khusus Demografi dan COVID-19, Juli 2020, hlm. 3338, https://www.researchgate.net/ publication/343305327_Inisiatif Masyarakat Indonesia di Masa Awal_Pandemi_COVID-19_Sebuah_ Upaya_Pembangunan_Kesehatan, diakses pada 3 November 2020.

Susila, Jaka. Hukum Sebagai Paradigma Fakta Sosial, Prosiding Seminar Nasional, Pengembangan Epistemologi Ilmu Hukum, 2015, hlm. 458-470, hlm. 461, https://publikasiilmiah.ums. ac.id/bitstream/handle/11617/5706 229.Jaka\%20Susila.pdf?sequen$\mathrm{ce}=1 \&$ isAllowed $=\mathrm{y}$, diakses pada 5 Agustus 2020.

Yuniar, Resty Woro. Covid-19: 'Indonesia Berpotensi Resesi' - Dampak Ekonomi 'Jauh Lebih Berat Ketimbang Krisis Moneter 1998, https://s.id/lTAGX, diakses pada tanggal 9 Juli 2020.

\section{Lain-lain}

Bangsa-Bangsa, Perserikatan. Report of the World Summit on Sustainable Development, Johannesburg, Afrika Selatan, 26 Agustus-4 September 2002, https:/ / papersmart.unon.org/resolution/uploads/2002-johannesburg declaration-n0263693.pdf, diakses pada 14 Juli 2020.

The Sustainable Development Goals Report 2016, https://unstats.un.org/ sdgs/report/2016/\#: : text=On\%20 1\%20January \%202016\%2C\%20the,over $\% 20$ the $\% 20$ next $\% 2015 \% 20$ years., diakses pada 4 November 2020.
World Summit on Sustainable Development (WSSD) Johannesburg Summit, Sustainable Development Goal Knowledge Platform, https:/ / sustainabledevelopment.un.org/milesstones/wssd, diakses pada 21 Juli 2020.

Bapna, Manish dan John Talberth. $Q \mathcal{E} A$ : What is a "Green Economy"?, Blog, World Resources Institute, https:// www.wri.org/blog/2011/04/qa-what-green-economy, diakses pada 21 Juli 2020.

Development, International Institute for Sustainable (IISD). https:// www.iisd.org/about-iisd/sustainable-development\#: : text= $\% 22$ Sustainable $\% 20$ development $\% 20$ is \% 20development $\% 20$ that, to $\% 20$ meet $\% 20$ their $\% 20$ own $\% 20$ needs. $\% 22$, diakses pada 9 Oktober 2020.

Kingdom, Sustainable Development Commission United, History of SD. http:/ / www.sd-commission.org. uk/pages/history_sd.html, diakses pada 24 Juli 2020.

Priorita. Komite Percepatan Penyediaan Infrastruktur, Proyek Strategis Nasional, https://kppip.go.id/proyek-strategis-nasional/, diakses pada 12 Oktober 2020.

Program. United Nation Environment, Green Economy, https://www. unenvironment.org/regions/asia-and-pacific/regional-initiatives/ supporting-resource-efficiency / green-economy, di akses pada 21 Juli 2020. 